\title{
Soil polychemical contamination on Beliy Island as key background and reference plot for Yamal region
}

\author{
Evgeny ABAKUMOV ${ }^{1 *}$, Georgy SHAMILISHVILIY ${ }^{1}$ and Andrey YURTAEV ${ }^{2}$ \\ ${ }^{1}$ Department of Applied Ecology, Saint-Petersburg State University, 16 Line of Vasilyevsky Island, \\ Saint Petersburg, 199178, Russia <e_abakumov@mail.ru> \\ ${ }^{2}$ Tyumen State University, Semakova str. 10, Tyumen, 625003, Russia <yurtaevgeo@yandex.ru> \\ * corresponding author
}

\begin{abstract}
Background concentrations of main trace elements and polycyclic aromatic hydrocarbons (PAHs) were investigated in pristine soils of the Beliy Island situated in the Kara Sea, Yamal autonomous region, North-West Siberia, Russia. Belyi Island is considered as reference landscpae for further investigation of soil polychemical contamination of the Yamal region. Three plots with different functional load (mature ecosystem, occasionally and permanently affected plots) were investigated with aim to evaluate the trend of long term polychemical effect on Stagnic Cryosols - benchmark soil type of the Yamal region. Accumulation of trace elements was not fixed in all soils investigated due to absence of direct sources of heavy metals on the territory of the Beliy Island. At the same time, there were essential alterations of PAHs fractional composition and content due to pronounced accumulation of the petroleum products combustion in the vicinity of the permanent meteorological station and former seasonal field base. The most intensive and statistically significant accumulation was noted for phenanthrene, anthracene, benzo[k]fluoranthene and benzo[a]pyrene. This indicates accumulation of the PAHs in soils, affected by the anthropogenic activity on the meteorological station. The most pronounced differences were revealed for the superficial layer of $0-5 \mathrm{~cm}$. Deeper horizons of soil did not show accumulation of contaminants. Data obtained can be used for organization of further monitoring of contamination of soils and landscapes in Yamal as developing and industrial region.
\end{abstract}

Key words: Arctic, Yamal, soil contamination, reference landscapes, trace elements, polycyclic aromatic compounds.

\section{Introduction}

The Russian Arctic is represented by cryogenic ecosystems with relatively sparse population. This region has been increasingly affected by industrial development, hydrocarbon and gas exploration, traffic effect and logistics in the 
recent decades (Walker et al. 2003, 2006, 2009). At the same time, pronounced climatic changes have occurred and affected the environmental quality of vast areas in the Russian Arctic. Increased human impact through intensive intentional or unintentional modification of terrestrial, freshwater, or marine environments, and predicted climatic changes are likely to result in a substantial and largely irreversible loss of biodiversity in the Arctic (ACIA 2005; Hudson et al. 2014, 2017). Ecosystems degradation may result in substantial diminishing benefits that future generations could derive from these ecosystems.

Soils underlayed by permafrost are widely distributed in landscapes of the Northern Hemisphere (Goryachkin 2010) including Russia, Canada, Greenland, China, and Mongolia. Permafrost-affected soils cover about $60 \%$ of the Russian territory (Kotlyakov and Khromova 2002). Permafrost has a pronounced effect on soil genesis and soil morphology. Firstly, it regulates the majority of chemical and physical processes resulting in transformation of the soil structure. Moreover, permafrost regulates directly and indirectly the efficiency of soil functioning in changing environments (Kimble 2004). That is why investigation of the geochemical state of permafrost affected soils is important issue of modern pedology and environmental science (Walker 2012).

Permafrost thaw and degradation caused by climate warming is considered as one of the most important processes of the soil evolution in the polar regions of Russia (Kaverin et al. 2014). Risks of permafrost thaw are related to increases of active layer thickness, which may lead to trace elements mobilization. Moreover, permafrost thawing may provide essential geochemical changes in huge landscapes of Western Siberia. This may result in increases of general geochemical conditions of soils and migration of trace elements.

Soils of the Yamal region play an important role in stabilization of pollutants, derived from exploration and mining activity. Published data on soil diversity and quality of this region are limited. Data, regarding soil organic matter quality (Ejarque and Abakumov 2016; Lodigyn et al. 2017), soil microbiota (Vlasov et al. 2014), active layer dynamics (Alekseev et al. 2017) are published for various part of this region. Data on trace elements content are also restricted. Only one soil profile was assessed in terms of geochemistry on Beliy Island (Tomahunas and Abakumov 2014; Alekseev et al. 2016) and several plots were assessed on main Yamal territory (Moskovchenko 1998, 2011, 2013).

Trace metals on the one hand are naturally present in parent rock and soils occurring in the form of sulfides, oxides, silicates, and carbonates. On the other hand, trace metals are considered as a main group of anthropogenic contaminants in soils (Antsibor et al. 2014). Studies conducted earlier showed that trace metals can reach the Arctic by different paths both of anthropogenic and natural origin (Barrie 1985, 1992; Akeredolu et al. 1994; Rovinsky et al. 1995). Metallurgical and energy industries are usually accompanied by the emission of acid-forming 
substances (Walker et al. 2003b). These substances can be transported over long distances and can contribute leaching of such labile elements as aluminum, cadmium and zinc (Nikitina et al. 2015). West Siberian Arctic environments are now intensively being developed in connection with the exploration of oil and gas fields. The problem of environmental restoration and environmental management is already very sharply risen in Yamal, Taz and southeast Gydan Peninsula (Khitun and Rebristaya 1997; Rebristaya and Khitun 1997).

Yamal region is actively developing in recent decades. It is one of the richest region in context of oil and gas deposits. Increasing of urban area leads to enhancing of pollution risk by sources connected to the settlements. However, nowadays, scientists and decision makers face a lack of knowledge about background concentration of the major trace elements. These data are needed for calculation of contamination indexes and evaluation of contamination levels. Lack of background concentration data makes these evaluations problematic. Another problem is the absence of data of the background concentration of polycyclic aromatic compounds (PAHs) in soil of mature and antropogenically affected landscapes. Limited data have been published regarding the concentrations of PAHs in soil of Northern Siberian part (Abakumov et al. 2015) and for taiga landscapes of Komi republic (Beznosikov et al. 2007; Beznosikov and Lodigin 2014).

The aim of this work was to estimate the current geochemical status and trace elements background concentration in soils of the Beliy Island, which is considered as key monitoring plot for Yamal region and Northern part of Western Siberia.

The objectives of investigation were (i) to assess main trace element background volumetric concentrations in soils with different anthropogenic load and (ii) to analyze concentrations of priority PAHs in soils of the Beliy Island.

Study area. - Investigation was conducted on the Beliy Island, situated in the Kara Sea $\left(73^{\circ} 15^{\prime}\right.$ N., $70^{\circ} 50^{\prime}$ E.), northern part of Yamal Peninsula (Fig. 1A). The total area of the island is about $199 \mathrm{sq} \mathrm{km}$ (Druzhinin et al. 2015). Land forms are represented by sea lowlands with average elevations about $12 \mathrm{~m}$ a.s.l. and terraces with elevation about 3-7 and 6-12 m a.s.l. (Fig. 1B) (Slagoda et al. 2013). The surface of the island is composed by marine sandy textured strata of the Holocene age and Late Pleisotcene sediments. The characteristic feature of Beliy Island climate is the predominance of cyclonic type of weather throughout the year, especially during transitional seasons and early winter. From December to February, in August and September there are fogs. Average annual air temperature is $-10.6^{\circ} \mathrm{C}$. Winter is cold, lasts about eight months. The average temperature of February (the coldest month) is $-24.2^{\circ} \mathrm{C}$, the average temperature of August (the warmest month) is $+5.3^{\circ} \mathrm{C}$. Minimal temperature is $-59^{\circ} \mathrm{C}$. Annual precipitation is $258 \mathrm{~mm}$ according to Trofimova and Balybina 


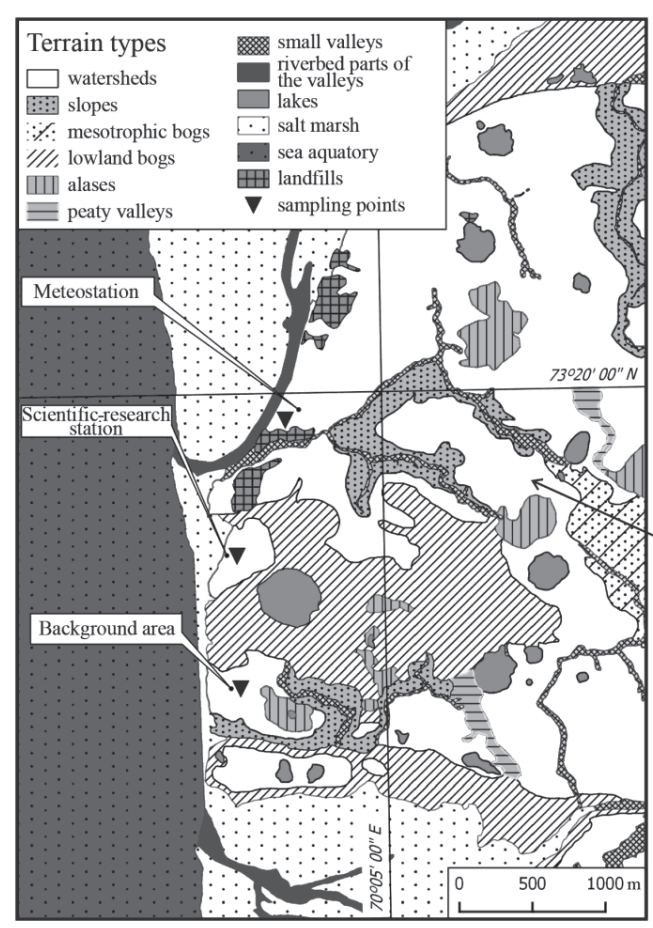

A
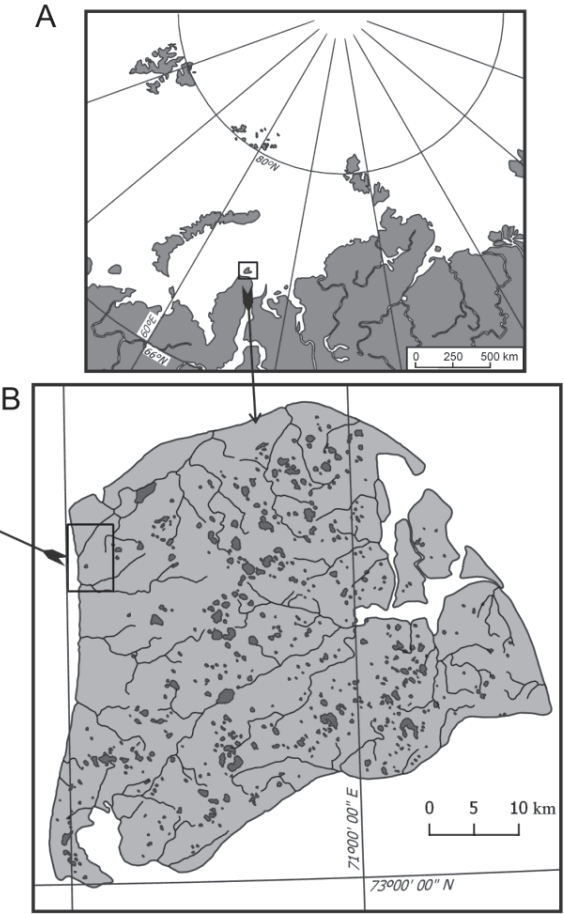

Fig. 1. Map of the Beliy Island and detailed scheme of the sampling plots: (A) location of Beliy Island in Yamal region; (B) Skecth of Beliy Island with insert map of study sites locations; (C) detailed landscape map of studied part of island.

(2014) and weather archives of Popov Meteorological Station (URL: http://rp5. $\mathrm{ru} /$ data obtained 10.02.2017).

Hydrographic network of the island is represented by a few small rivers, streams and pounds as well as numerous lakes. Total area occupied by lakes is $7 \%$ of island areas. Landscape is overmoistened and therefore soil demonstrates stagnic features.

Ecosystem type is classified as Arctic tundra (Rebristaya 2013; Makarova et al. 2015), with presence of grasses (Carex, Eriophorum, Juncus), bryophyta (Racomitrium, Pogonatum, Dicranum, Sphagnum) and lichens (Cladina, Cladonia). A few areas are occupied by willow (Salix).

Soil cover is presented mainly by gleyic (stagnic) soils on the watersheds, Stagnic Histosols on the permafrost peatlands and by soil of tundra patterned grounds on the gentle slopes. Coastal part is presented mainly by Arenosols and Fluvisols (Alyabina et al. 2014). 


\section{Material and methods}

Selected sampling plots were situated on the north-west part of the island, where the anthropogenic impact is well pronounced (Fig. 1C). The area has been subjected to anthropogenic impact over last 84 years. The meteorological station after the name of M.V. Popov was established on the North-West coast of Rogozyn stream in 1933. Later there was also military camp, which now is closed, and lands in surroundings with waste disposals were reclaimed and waste storages were partially removed (Mazharov 2012). Meteorological and scientificresearch stations use diesel generators for electricity and heating. That is why variously effected soils contaminated with polycyclic aromatic compounds can be study in this area.

The sampling plots were established on the same land forms, within equal type of vegetation and plant cover. Unaffected plots (mature soil) were situated in pristine tundra, affected plots next to meteorological and scientific-research stations. Soil cover is represented by gleysols, formed of loamy sands. The degree of hisitc material transformation varies in investigated Stagnosols. They can be divided to Turbic, Reductic and Histic soils (Shishov et al. 2014).

Sampling in all three plots was conducted on Stagnosols with pronounced reduction features $(\mathrm{O}-\mathrm{Gf}-\mathrm{G})$. The average thickness of soil profile was $3-4 \mathrm{~cm}$. Histic material was slightly decomposed. Active layer thickness was about $40-5 \mathrm{~cm}$, which were established on the base of vertical electric sounding methodology application (Abakumov and Tomashunas 2016).

Sampling strategy. - Soil has been sampled from soil pits with the size $30 \times 30 \mathrm{~cm}$ from the three depths $0-5,5-10$ and $10-15 \mathrm{~cm}$ with the aim to evaluate redistribution and migration of the contaminants. Each plot included 4 sampling points, i.e. 4 replicates. Sampling points were situated in the corners of the square with the length of the side about $50 \mathrm{~m}$. Totally 36 bulk samples were sampled from all three plots. The Edelman drill (modification for combined soils) with stainless nozzle (prewashed with acetone) was used for sampling. Collected samples were stored in double sterile polyethylene bags, labeled and transported to the laboratory. The samples were air-dried at the room temperature, separated from roots and debris and passed through $2 \mathrm{~mm}$ polyethylene sieve prior to chemical analysis.

PAHs, petroleum products and metal content analysis. - A total of 14 PAHs as well as their individual concentrations were analyzed in selected samples, including naphthalene (NAP), acenaphthene (ANA), fluorene (FLU), phenanthrene (PHE), anthracene (ANT), fluoranthene (FLT), pyrene (PYR), benzo(a)anthracene $(\mathrm{BaA})$, chrysene $(\mathrm{CHR})$, benzo(b)fluoranthene $(\mathrm{BbF})$, benzo(k)fluoranthene $(\mathrm{BkF})$, benzo(a)pyrene $(\mathrm{BaP})$, dibenz(ah)anthracene (DBA) 
and benzo(g,h,i)perylene (BPE). Not all 16 PAHs were determined because the concentrations were too low for detection limits.

PAHs content in samples was determined on the basis of US EPA (1996a) method 8310, national standard method PND F 16.1:2:2.2:3.62-09 (2009), and Gabov et al. $(2007,2008)$. Extraction of the PAHs was carried out at room temperature with methylene chloride (high purity grade) and ultrasonic treatment via Branson 5510 ultrasonic bath (USA, power $469 \mathrm{~W}$, working frequency $42 \mathrm{kHz}$ ) following the US EPA (1996b) method 3550b. Solvent removal (evaporation) was carried out with Kuderna-Danish concentrator (Supelco). PAHs fractions were purified by consecutive chromatography in columns filled with aluminum oxide (Brockman activity grade 2-3, Neva Reaktiv) and silica gel (Fluka) according to the US EPA (1996c) purification method 3660c. The purity was controlled by the absence of peaks in the blank chromatogram. A standard mixture of 14 PAHs (Supelco) with the concentrations of each component in the range of $100-2000 \mu \mathrm{g} / \mathrm{cm}^{3}$ was used to prepare the standard PAH solutions. Qualitative and quantitative determination of PAHs in soils was carried out by reverse-phase high-performance liquid chromatography (HPLC) in gradient mode with spectrofluorimetric detection via chromatograph "Lyumahrom" ("Lumex", Russia). Chromatography was performed at $30^{\circ} \mathrm{C}$ on a column Supelcosil ${ }^{\mathrm{TM}}$ LC-PAH n5 $\mu \mathrm{m}(25 \mathrm{~cm} \times 2.1 \mathrm{~mm})$. Mobile phase was provided with acetonitrile-water gradient. Samples of $10 \mu \mathrm{l}$ volume were injected using injection valve. Individual PAHs were identified by the time of retention and comparison of fluorescence spectra of the components coming from the column with spectra of the standard PAHs. Quantitative analysis of PAHs was performed by external standard method. For the quality assurance purposes Standard reference materials (1944 New York/New Jersey Waterway Sediment (National Institute of Standards and Technologies NIST, USA) containing a mixture of 14 PAHs were subjected to the procedure described above. The error of measuring the PAHs (benz-(a)-pyrene) in the soils was 35\% in the range of $5-40 \mathrm{ng} / \mathrm{g}$ and $25 \%$ in the range of 40-2000 $\mathrm{ng} / \mathrm{g}$ with a confidence probability of $\mathrm{P}=0.95$. Obtained results were compared with soil guideline for benzo(a) pyrene in soil (20 ng/g) according to Russian legislation (GN 2.1.7.2041-06 2006). Benzo(a)pyrene total potency equivalents were calculated in order to provide comparison of the PAHs content with soil guideline value for benzo(a)pyrene in soil. The benzo(a)pyrene total potency equivalents for a soil sample are simply calculated by multiplying the concentration of each analyzed individual PAH in the sample by its benzo(a)pyrene toxic equivalency factor according to the World Health Organization (WHO/IPCS 1998) scheme. Special molecular markers and ratios, proposed by Yunker et al. (2002) and a total combustion PAHs index, reported by Hwang et al. (2003) were applied for PAH sources apportionment. Applied markers allow to distinguish between pyrogenic and petrogenic sources of PAHs, namely: ANT/(ANT+PHE), FLT/(FLT+PYR), BaA/(BaA+CHR), IPY/ (IPY+BPE), CombPAH/14PAH and BaP/BPE. 
Studied soils were examined for the content of the petroleum products (PP). It was determined via fluid analyzer "FLYUORAT-02" according to national standard method PND F 16.1:2.21-98 (1998) - the method of fluorimetric measurement of the mass fraction of petroleum products in the soil based on the extraction of the sample with methylene chloride and hexane (chloroform) with subsequent purification of the extract by column chromatography followed by measurement of fluorescence intensity in the purified extract on the fluid analyzer. Obtained results were compared with existing approximately permissible concentrations of $P P$ for tundra gley, tundra and peat soils $(700 \mathrm{mg} / \mathrm{kg})$ according to Russian legislation (GN 2.1.7.2511-09 2009).

Trace element contents have been investigated (copper, lead, cadmium, zinc, nickel, arsenic and mercury) in selected soil samples. Forms of metals, extracted in Aqua Regia $(\mathrm{Cu}, \mathrm{Pb}, \mathrm{Cd}, \mathrm{Zn}, \mathrm{Ni}, \mathrm{Mn}$ and $\mathrm{As})$ were determined according to national standard method PND F 16.1:2.3:3.11-98 (1998) with use of atomic emission spectrometer with inductively coupled argon plasma (Spectro Ciros, Germany). Obtained results were compared with existing maximum permissible concentrations and approximate permissible concentrations according to Russian legislation (GN 2.1.7.2041-06 2006; GN 2.1.7.2511-09 2009; SanPiN 42-1284433-87 1987).

Anthropogenic input of heavy metals to soil was additionally evaluated using geo-accumulation index $\left(\mathrm{I}_{\text {geo }}\right)$ approach. Geo-accumulation index (Muller 1979) is widely used to study pollution levels of trace metals in soils. It enables the assessment of pollution by comparing current and pristine concentrations of the contaminants. Calculation of geo-accumulation index was performed using the following Equation (1):

$$
\mathrm{I}_{\text {geo }}=\log _{2}\left[\frac{C_{n}}{k B_{n}}\right]
$$

Where $C_{n}$ is the concentration of the trace element in the enriched sample $[\mathrm{mg} / \mathrm{kg}]$; $B_{n}$ is the geochemistry background value of the same element in soil $[\mathrm{mg} / \mathrm{kg}]$; $k$ is the factor introduced to minimize the effect of possible variations of soil background value due to lithogenic effects. Its recommended value is 1.5. The degree of soil pollution is assessed according to seven contamination classes (Forstner et al. 1990) in order of increasing numerical value of the index.

Statistics. - Statistical treatment of the data was carried out via STATISTICA 10.0 software. One-way ANOVA was applied in order to test statistical significance of differences between obtained data. The essence of the method is based on estimation of the significance of average differences between three or more independent groups of data combined by one feature (factor). Post-hoctest (Fisher LSD) was used to provide detailed evaluation of average differences between analyzed groups of data. A feature of post-hoc-test is application of 
intra-group mean squares for the assessment of any pair averages. Differences were considered to be significant at the $95 \%$ confidence level. Concentrations of organic and inorganic contaminants were analyzed at least in 4 replications. Calculated mean concentrations were provided with standard deviations $(a \pm b)$.

\section{Results and discussion}

Trace elements and petroleum products concentrations. - The results has shown that heavy metals contents in soils of the studied objects are below the maximum permissible concentration (MPC) for each analyzed element, except a single sample collected near meteorological station from 5-10 cm soil layer, exhibiting high concentration of lead $(54.10 \mathrm{mg} / \mathrm{kg})$ which is 1.7 times higher than MPC for lead in sandy and sandy-coarse soil $(32 \mathrm{mg} / \mathrm{kg})$, however, certain elements were characterized by a gradual increase in concentration with depth (Table 1). It should be noted that existing Russian soil guide manuals for heavy metals in soil and other inorganic and organic pollutants referred to MPCs or approximatively permissible concentrations which does not take into account organic soils (peats). There is only a single soil guideline level for HMs according to Russian legislation without differentiation of the land use types, setting the maximal permissible concentrations (MPC) of these elements in soils primarily of an agricultural land use, no ecological thresholds have been designed yet. Comparing to international soil guidelines, for instance, CCME guidelines for copper $(63 \mathrm{mg} / \mathrm{kg}$ for agricultural and residential land uses, $100 \mathrm{mg} / \mathrm{kg}$ for others), lead (70 mg/kg for agricultural land use, $140 \mathrm{mg} / \mathrm{kg}$ for residential, 260 $\mathrm{mg} / \mathrm{kg}$ for commercial and 400 for industrial), zinc $(200 \mathrm{mg} / \mathrm{kg}$ for agricultural and residential land uses, $380 \mathrm{mg} / \mathrm{kg}$ for others) and cadmium $(14 \mathrm{mg} / \mathrm{kg}$ for agricultural land use, $10 \mathrm{mg} / \mathrm{kg}$ for residential land use, $27 \mathrm{mg} / \mathrm{kg}$ for others) Russian MPCs seem to be of a lower value (about 28 time lower for $\mathrm{Cd}$ for agricultural land use).

In turn, threshold value for a majority of trace metals in peaty and peaty-gley soils must be more strict, due to strong acidic reaction of the soil solution, which affects the mobility of elements, causing their leaching to the subsoil layers and may lead to ground water contamination. Nickel, lead and arsenic were found to have a maximum accumulation in the $5-10 \mathrm{~cm}$ layer, which is probably associated with cryogenic mass exchange. Average concentrations of analyzed trace metals were found to fluctuate around the background level. Calculated Igeo indices suggested that studied soils are characterized by I class - practically unpolluted with almost all values below the 0 level (Table 2). Several samples taken from 5-10 and 10-15 cm layers showed Igeo values of $\mathrm{Pb}, \mathrm{Cu}$ and $\mathrm{Zn}$ above the 0 level, indicating II Igeo-class - practically unpolluted to moderately polluted soils. The significant differences in heavy metals contents in soil between 
the studied objects were not found (One-way ANOVA $\mathrm{p}<0.10-0.90$ ), refer to Table 3. Defined petroleum products (PP) concentrations in analyzed samples were also below the permissible level, reaching the background soil values.

Table 1

Heavy metals and petroleum products contents in studied soils.

\begin{tabular}{|c|c|c|c|c|c|c|}
\hline $\begin{array}{l}\text { Chemical } \\
\text { element }\end{array}$ & $\begin{array}{l}\text { Sampling } \\
\text { depth }\end{array}$ & $\begin{array}{l}\text { Meteorological } \\
\text { station } \\
(n=4) \\
\text { Mean } \pm \text { SD }\end{array}$ & $\begin{array}{l}\text { Scientific- } \\
\text { research } \\
\text { station } \\
(\mathrm{n}=4) \\
\text { Mean } \pm \mathrm{SD}\end{array}$ & $\begin{array}{c}\text { Background area } \\
(\mathrm{n}=4) \\
\text { Mean } \pm \mathrm{SD}\end{array}$ & $\begin{array}{l}\text { MPC } \\
\text { (Soil } \\
\text { guideline } \\
\text { value) }\end{array}$ & $\begin{array}{c}p \text { One-way } \\
\text { ANOVA }\end{array}$ \\
\hline \multirow{3}{*}{$\mathrm{Cu}$} & $0-5$ & $6.57 \pm 2.85$ & $6.10 \pm 2.45$ & $4.77 \pm 2.21$ & \multirow{3}{*}{33.00} & 0.60 \\
\hline & $5-10$ & $7.80 \pm 4.31$ & $8.32 \pm 2.57$ & $5.29 \pm 3.15$ & & 0.44 \\
\hline & $10-15$ & $4.77 \pm 3.64$ & $7.95 \pm 1.45$ & $6.02 \pm 3.46$ & & 0.37 \\
\hline \multirow{3}{*}{$\mathrm{Pb}$} & $0-5$ & $5.52 \pm 1.49$ & $5.75 \pm 1.68$ & $5.00 \pm 1.56$ & \multirow{3}{*}{32.00} & 0.79 \\
\hline & $5-10$ & $54.10 \pm 55.90$ & $6.00 \pm 1.18$ & $5.00 \pm 1.94$ & & 0.10 \\
\hline & $10-15$ & $3.92 \pm 1.33$ & $6.32 \pm 0.84$ & $5.12 \pm 1.91$ & & 011 \\
\hline \multirow{3}{*}{$\mathrm{Cd}$} & $0-5$ & $0.12 \pm 0.03$ & $0.18 \pm 0.10$ & $0.13 \pm 0.02$ & \multirow{3}{*}{0.50} & 0.39 \\
\hline & $5-10$ & $0.14 \pm 0.04$ & $0.14 \pm 0.05$ & $0.15 \pm 0.04$ & & 0.92 \\
\hline & $10-15$ & $0.11 \pm 0.01$ & $0.17 \pm 0.06$ & $0.16 \pm 0.05$ & & 0.20 \\
\hline \multirow{3}{*}{$\mathrm{Zn}$} & $0-5$ & $26.77 \pm 19.71$ & $20.42 \pm 6.35$ & $13.52 \pm 5.29$ & \multirow{3}{*}{55.00} & 0.36 \\
\hline & $5-10$ & $16.80 \pm 6.75$ & $22.00 \pm 5.29$ & $14.55 \pm 6.21$ & & 0.28 \\
\hline & $10-15$ & $13.80 \pm 7.17$ & $22.25 \pm 3.50$ & $15.05 \pm 6.89$ & & 0.16 \\
\hline \multirow{3}{*}{$\mathrm{Ni}$} & $0-5$ & $9.55 \pm 5.01$ & $10.92 \pm 4.01$ & $10.97 \pm 6.77$ & \multirow{3}{*}{20.00} & 0.91 \\
\hline & $5-10$ & $10.02 \pm 4.50$ & $13.00 \pm 3.37$ & $10.50 \pm 6.14$ & & 0.65 \\
\hline & $10-15$ & $8.25 \pm 5.31$ & $13.00 \pm 2.94$ & $11.45 \pm 6.33$ & & 0.43 \\
\hline \multirow{3}{*}{ Mn } & $0-5$ & $100.25 \pm 36.33$ & $162.50 \pm 45.73$ & $300.50 \pm 273.42$ & \multirow{3}{*}{1500.00} & 0.25 \\
\hline & $5-10$ & $88.25 \pm 36.21$ & $92.25 \pm 37.83$ & $105.25 \pm 88.31$ & & 0.91 \\
\hline & $10-15$ & $68.50 \pm 36.08$ & $120.25 \pm 76.99$ & $89.25 \pm 54.63$ & & 0.48 \\
\hline \multirow{3}{*}{ PP } & $0-5$ & $5.57 \pm 2.79$ & $0.44 \pm 0.22$ & $3.36 \pm 1.68$ & \multirow{3}{*}{700.00} & 0.24 \\
\hline & $5-10$ & $9.97 \pm 9.36$ & $8.35 \pm 3.22$ & $9.70 \pm 6.98$ & & 0.94 \\
\hline & $10-15$ & $7.40 \pm 4.41$ & $5.82 \pm 0.71$ & $8.80 \pm 4.07$ & & 0.51 \\
\hline
\end{tabular}


Seven classes of geo-accumulation index

\begin{tabular}{|c|c|l|}
\hline$I_{\text {geo }}$ class & End member values & \multicolumn{1}{c|}{ Pollution level } \\
\hline I & $I_{g e o}<0$ & Practically unpolluted \\
\hline II & $0 \leq I_{g e o}<1$ & Practically unpolluted to moderately polluted \\
\hline III & $1 \leq I_{g e o}<2$ & Moderately polluted \\
\hline IV & $2 \leq I_{g e o}<3$ & Moderately polluted to highly polluted \\
\hline V & $3 \leq I_{g e o}<4$ & Highly polluted \\
\hline VI & $4 \leq I_{g e o}<5$ & Highly polluted to extremely polluted \\
\hline VII & $I_{g e o}>5$ & Extremely polluted \\
\hline
\end{tabular}

Table 3

Geo-accumulation index (Igeo) in soils investigated

\begin{tabular}{|c|c|c|c|}
\hline \multirow{2}{*}{$\begin{array}{l}\text { Chemical } \\
\text { element }\end{array}$} & \multirow{2}{*}{ Sampling depth } & \multicolumn{2}{|c|}{$I_{g e o}$} \\
\hline & & Meteorological station & Scientific-research station \\
\hline \multirow{3}{*}{$\mathrm{Cu}$} & $0-5$ & -0.29 & -0.40 \\
\hline & $5-10$ & -0.04 & 0.05 \\
\hline & $10-$ & -0.75 & -0.02 \\
\hline \multirow{3}{*}{$\mathrm{Pb}$} & $0-5$ & -045 & -0.39 \\
\hline & $5-10$ & 2.84 & -0.33 \\
\hline & $10-15$ & -095 & -0.26 \\
\hline \multirow{3}{*}{$\mathrm{Cd}$} & $0-5$ & -0.87 & -0.29 \\
\hline & $5-10$ & -0.65 & -0.65 \\
\hline & $10-15$ & -1.14 & -0.37 \\
\hline \multirow{3}{*}{$\mathrm{Zn}$} & $0-5$ & 0.32 & -0.08 \\
\hline & $5-10$ & -0.36 & 0.03 \\
\hline & $10-15$ & -0.64 & 0.05 \\
\hline \multirow{3}{*}{$\mathrm{Ni}$} & $0-5$ & -0.78 & -0.59 \\
\hline & $5-10$ & -0.71 & -0.34 \\
\hline & $10-15$ & -0.99 & -0.34 \\
\hline \multirow{3}{*}{ Mn } & $0-5$ & -1.30 & -0.61 \\
\hline & $5-10$ & -1.49 & -1.42 \\
\hline & $10-15$ & -1.85 & -1.04 \\
\hline
\end{tabular}


Polycyclic aromatic hydrocarbons contents. - The levels of 14 PAHs analyzed in soils are shown in Table 4. Total PAH concentrations in studied soils were found to range from 100 to $240 \mathrm{ng} / \mathrm{g}$ (sum of 14 priority PAH, hereafter referred to $14 \mathrm{PAH})$. The vast majority of PAHs were characterized by concentrations around $6 \mathrm{ng} / \mathrm{g}$. The highest $14 \mathrm{PAH}$ levels were observed in soil samples collected from meteorological station at $0-5 \mathrm{~cm}$ layer reaching an average of $234 \mathrm{ng} / \mathrm{g}$. Concentrations found near scientific-research station were substantially lower than those near meteorological station, with an average value changing with a depth from 113 to $109 \mathrm{ng} / \mathrm{g}$.

The bar chart showing the contribution of PAH with different ring numbers to the sum of PAH in soils is depicted in Fig. 2. The sum of organic pollutants is mostly dominated by low molecular weight PAH with 2-3 rings. Portion of 2-ringed PAH compounds in soils of meteorological and scientific-research stations surroundings accounts for 10-20\% of the sum of PAHs in soil. Three ringed PAHs including such compounds as ANA, FLU, PHE and ANT contributed up to $40 \%$ of the sum of PAH insignificantly varying between studied objects. The rest portion is accounted for the heavy molecular PAHs primarily with 4 rings in structure (20-35\%). Calculated benzo(a)pyrene total potency equivalents (Table 4) for the sum of PAHs in soil suggest hence that local soils are characterized by total PAH concentrations significantly exceeding soil guideline value for benzo(a)pyrene in soil $(20 \mathrm{ng} / \mathrm{g})$.

Table 4

PAHs content in studied soils. All values in $\mathrm{ng} / \mathrm{g}$.

Bolded values indicate significant differences.

\begin{tabular}{|c|c|c|c|c|c|}
\hline \multirow{4}{*}{ PAH } & $\begin{array}{c}\text { Sampling } \\
\text { depth }\end{array}$ & $\begin{array}{c}\text { Meteorological } \\
\text { station } \\
(\mathrm{n}=4) \\
\text { Mean } \pm \text { SD }\end{array}$ & $\begin{array}{c}\text { Scientific- } \\
\text { research station } \\
(\mathrm{n}=4) \\
\text { Mean } \pm \text { SD }\end{array}$ & $\begin{array}{c}\text { Background area } \\
(\mathrm{n}=4) \\
\text { Mean } \pm \text { SD }\end{array}$ & $\begin{array}{c}p \text { One-way } \\
\text { ANOVA }\end{array}$ \\
\hline \multirow{4}{*}{ NAP } & $0-5$ & $<20.001$ & $<20.00$ & $<20.00$ & - \\
\cline { 2 - 6 } & $5-10$ & $<20.00$ & $<20.00$ & $<20.00$ & - \\
\cline { 2 - 7 } & $10-15$ & $<20.00$ & $<20.00$ & $<20.00$ & - \\
\hline \multirow{4}{*}{ ANA } & $0-5$ & $<6.00$ & $<6.00$ & $<6.00$ & - \\
\cline { 2 - 7 } & $5-10$ & $<6.00$ & $<6.00$ & $<6.00$ & - \\
\cline { 2 - 7 } & $10-15$ & $<6.00$ & $<6.00$ & $<6.00$ & - \\
\hline \multirow{4}{*}{ FLU } & $0-5$ & $6.07 \pm 0.19$ & $<6.00$ & $<6.00$ & $<0.60$ \\
\cline { 2 - 7 } & $5-10$ & $<6.00$ & $<6.00$ & $<6.00$ & - \\
\cline { 2 - 7 } & $10-15$ & $<6.00$ & $<6.00$ & $<6.00$ & $<$ \\
\hline \multirow{4}{*}{ PHE } & $0-5$ & $25.96 \pm 15.26$ & $9.53 \pm 3.86$ & $8.72 \pm 2.25$ & $<\mathbf{0 . 0 4}$ \\
\cline { 2 - 7 } & $5-10$ & $10.88 \pm 5.49$ & $6.86 \pm 1.72$ & $7.49 \pm 1.05$ & $<0.24$ \\
\cline { 2 - 7 } & $10-15$ & $10.88 \pm 5.49$ & $6.86 \pm 1.72$ & $7.47 \pm 1.05$ & $<0.24$ \\
\hline
\end{tabular}


Table 4 continued

\begin{tabular}{|c|c|c|c|c|c|}
\hline PAH & $\begin{array}{l}\text { Sampling } \\
\text { depth }\end{array}$ & $\begin{array}{l}\text { Meteorological } \\
\text { station } \\
(\mathrm{n}=4) \\
\text { Mean } \pm \text { SD }\end{array}$ & $\begin{array}{c}\text { Scientific- } \\
\text { research station } \\
(n=4) \\
\text { Mean } \pm \text { SD }\end{array}$ & $\begin{array}{c}\text { Background area } \\
(\mathrm{n}=4) \\
\text { Mean } \pm \mathrm{SD}\end{array}$ & $\begin{array}{c}p \text { One-way } \\
\text { ANOVA }\end{array}$ \\
\hline \multirow{3}{*}{ ANT } & $0-5$ & $2.45 \pm 1.61$ & $<1.00$ & $1.06 \pm 0.12$ & $<0.02$ \\
\hline & $5-10$ & $1.11 \pm 0.22$ & $<1.00$ & $<1.00$ & $<0.40$ \\
\hline & $10-15$ & 1.00 & $<1.00$ & $<1.00$ & - \\
\hline \multirow{3}{*}{ FLT } & $0-5$ & $40.77 \pm 26.61$ & $<20.00$ & $<20.00$ & $<0.14$ \\
\hline & $5-10$ & $24.36 \pm 8.72$ & $<20.00$ & $<20.00$ & $<0.40$ \\
\hline & $10-15$ & 20.00 & $<20.00$ & $<20.00$ & - \\
\hline \multirow{3}{*}{ PYR } & $0-5$ & $32.86 \pm 18,91$ & $<20.00$ & $<20.00$ & $<0.22$ \\
\hline & $5-10$ & $23.76 \pm 7,52$ & $<20.00$ & $<20.00$ & $<0.40$ \\
\hline & $10-15$ & 20.00 & $<20.00$ & $<20.00$ & - \\
\hline \multirow{3}{*}{$\mathrm{BaA}$} & $0-5$ & $14.67 \pm 10.42$ & $<6.00$ & $6.37 \pm 0.75$ & $<0.13$ \\
\hline & $5-10$ & $8.88 \pm 5.76$ & $<6.00$ & $<6.00$ & $<0.40$ \\
\hline & $10-15$ & 6.00 & $<6.00$ & $<6.00$ & - \\
\hline \multirow{3}{*}{ CHR } & $0-5$ & $15.63 \pm 12.37$ & $<3.00$ & $4.50 \pm 3.00$ & $<0,07$ \\
\hline & $5-10$ & $3.00 \mathrm{e}$ & $<3.00$ & $<3.00$ & - \\
\hline & $10-15$ & $<3.00$ & $<3.00$ & $<3.00$ & - \\
\hline \multirow{3}{*}{$\mathrm{BbF}$} & $0-5$ & $19.61 \pm 15.96$ & $<6.00$ & $7.87 \pm 3.75$ & $<0.14$ \\
\hline & $5-10$ & $10.86 \pm 9.72$ & $<6.00$ & $<6.00$ & $<0.40$ \\
\hline & $10-15$ & $<6.00$ & $<6.00$ & $<6.00$ & - \\
\hline \multirow{3}{*}{$\mathrm{BkF}$} & $0-5$ & $9.56 \pm 7.01$ & $<1.00$ & $1.00 \mathrm{e}$ & $<0.04$ \\
\hline & $5-10$ & $1.00 \mathrm{e}$ & $<1.00$ & $<1.00$ & - \\
\hline & $10-15$ & $1.00 \mathrm{e}$ & $<1.00$ & $<1.00$ & $<0.40$ \\
\hline \multirow{3}{*}{$\mathrm{BaP}$} & $0-5$ & $14.60 \pm 10.48$ & $<1.00$ & $<1.00 \mathrm{e}$ & $<0.03$ \\
\hline & $5-10$ & $1.00 \mathrm{e}$ & $<1.00$ & $<1.00$ & - \\
\hline & $10-15$ & $1.00 \mathrm{e}$ & $<1.00$ & $<1.00$ & $<0.40$ \\
\hline \multirow{3}{*}{ DBA } & $0-5$ & $<6.00$ & $<6.00$ & $<6.00$ & - \\
\hline & $5-10$ & $<6.00$ & $<6.00$ & $<6.00$ & - \\
\hline & $10-15$ & $<6.00$ & $<6.00$ & $<6.00$ & $<0.40$ \\
\hline \multirow{3}{*}{ BPE } & $0-5$ & $19.96 \pm 10.52$ & $7.00 \mathrm{e} \pm 1.15$ & $8.37 \pm 2.09$ & $<0.49$ \\
\hline & $5-10$ & $7.99 \pm 3.35$ & 6.00 & $6.18 \pm 0.36$ & $<0.32$ \\
\hline & $10-15$ & $7.99 \pm 3.35$ & 6.00 & $6.18 \pm 0.36$ & 0.32 \\
\hline
\end{tabular}


Table 4 continued

\begin{tabular}{|c|c|c|c|c|c|}
\hline PAH & $\begin{array}{l}\text { Sampling } \\
\text { depth }\end{array}$ & $\begin{array}{c}\text { Meteorological } \\
\text { station } \\
(n=4) \\
\text { Mean } \pm \text { SD }\end{array}$ & $\begin{array}{c}\text { Scientific- } \\
\text { research station } \\
(n=4) \\
\text { Mean } \pm \text { SD }\end{array}$ & $\begin{array}{c}\text { Background area } \\
(\mathrm{n}=4) \\
\text { Mean } \pm \mathrm{SD}\end{array}$ & $\begin{array}{c}p \text { One-way } \\
\text { ANOVA }\end{array}$ \\
\hline \multirow{3}{*}{$\Sigma$ PAHs } & $0-5$ & $234.14 \pm 4.01$ & $112.53 \pm 6.44$ & $116.89 \pm 5.32$ & $<0.001$ \\
\hline & $5-10$ & $130.84 \pm 11.83$ & $108.86 \pm 3.21$ & $109 / 67 \pm 2.17$ & $<0.001$ \\
\hline & $10-15$ & $114.87 \pm 7.89$ & $108.86 \pm 4.58$ & $109.65 \pm 5.09$ & $<0.001$ \\
\hline \multirow{3}{*}{$\begin{array}{l}\text { BaP-equiv- } \\
\text { alents for } \\
\sum \text { PAHs }\end{array}$} & $0-5$ & 49.50 & 36.89 & 32.74 & \\
\hline & $5-10$ & 33.29 & 36.88 & 32.48 & \\
\hline & $10-15$ & 32.50 & 36.88 & 32.48 & \\
\hline
\end{tabular}

$<20.00$ indicated the detection limits for particular substances.

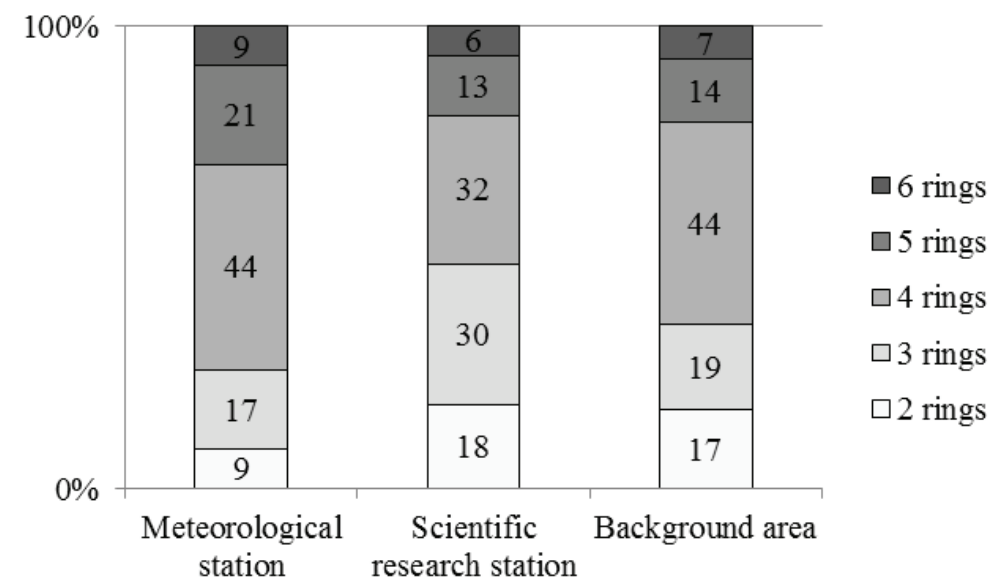

Fig. 2. Contribution of PAH with different ring numbers to the sum of PAH in soils.

While a domination of high molecular weight PAH fraction indicates a combustion origin (pyrogenic), enrichment of low molecular weight PAHs is common in fresh fuels (petrogenic) (Masclet et al. 1987; Budzinski et. al. 1997). Special molecular markers and ratios, proposed by Yunker et al. (2002) and a total combustion PAHs index, reported by Hwang et al. (2003) were applied for PAH sources apportionment. Applied markers allow to distinguish between pyrogenic and petrogenic sources of PAHs, namely: ANT/(ANT+PHE), FLT/(FLT+PYR), $\mathrm{BaA} /(\mathrm{BaA}+\mathrm{CHR}), \mathrm{IPY} /(\mathrm{IPY}+\mathrm{BPE}), \mathrm{CombPAH} / 14 \mathrm{PAH}$ and BaP/BPE. Calculated ratios for samples taken from meteorological and scientific-research stations exhibited numbers that point to a domination of pyrogenically formed PAHs.

Several markers are indicative of certain combustion sources of PAHs, appointing to gasoline, diesel, crude oil or grass, coal and wood combustion origins, namely: FLT/(FLT+PYR), BaA/(BaA+CHR), IPY/(IPY+BPE) (Fig. 3). The calculated 
A

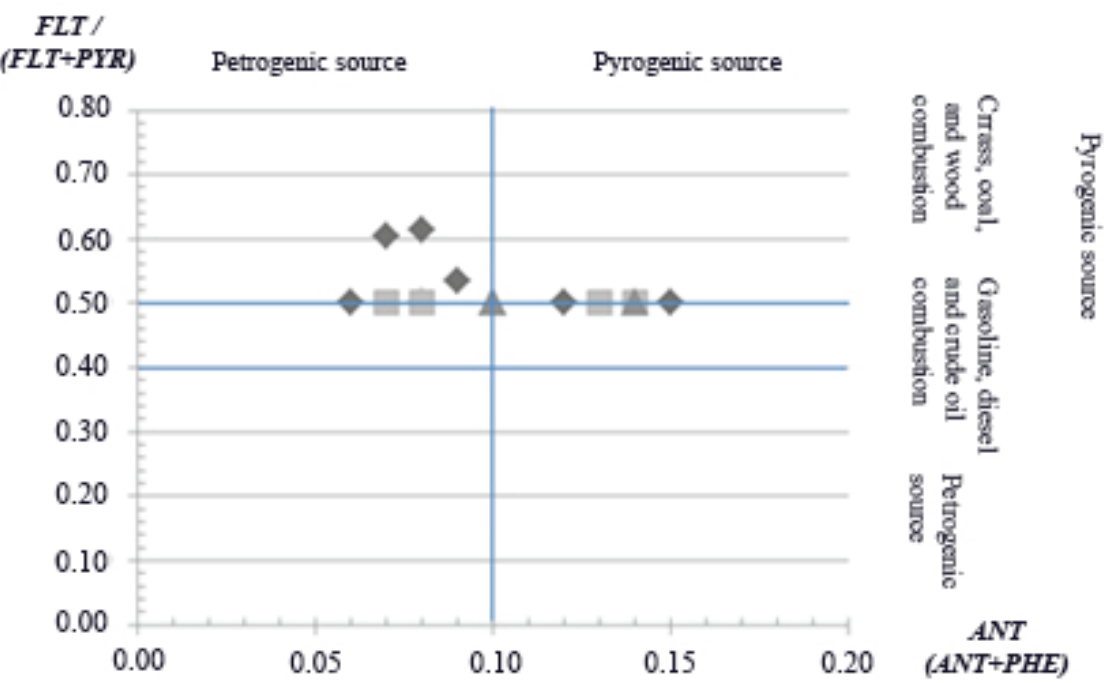

$\bullet$ Meteorological station

Scientific-research station

$\triangle$ Background area

B Pyrogenic source:

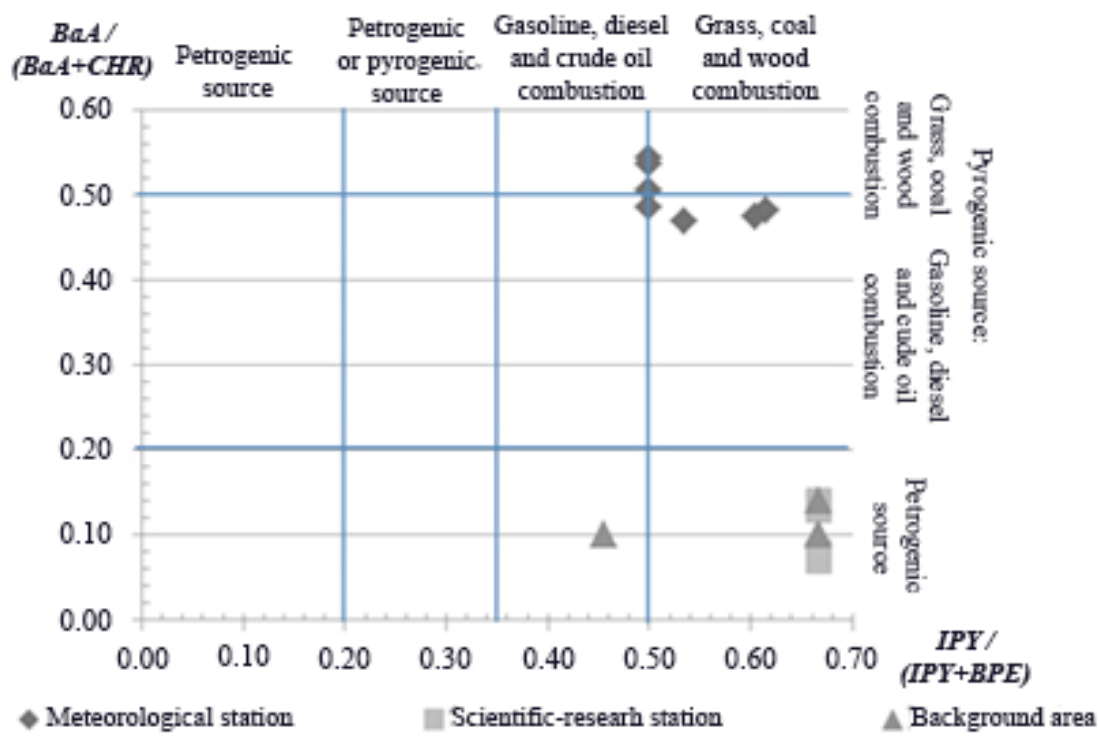

Fig. 3. PAH molecular ratio cross plots: (A) FLT to FLT + PYR ratio categories in vertical scale, ANT to ANT + PHE ratio in horizontal; (B) BaA to BaA + CHR ratio categories in vertical scale, IPY to IPY + BPE ratio in horizontal. 
FLT/(FLT+PYR) (0.49-0.51) and IPY/(IPY+BPE) (0.30-40) and BaP/BPE (1.20-1.64) values point to a domination of diesel and oil combustion. However, obtained values of FLT/(FLT+PYR) and $\mathrm{BaA} /(\mathrm{BaA}+\mathrm{CHR})$ ratios suggested that coal and wood combustion have a certain role in PAHs origination as well (MacAskill et al. 2016). It is important to note that the shift of heavy and low molecular PAHs ratio towards the heavy ones cannot be explained only by anthropogenic factor, the degradation of lighter PAHs due to environmental factors such as photolysis under the direct sun rays in the topsoil layers, as well as thermal degradation, biological uptake and biodegradation may play a significant role as well (Behymer and Hites 1985; Wild and Jones 1995; Wang and Cadman 1998; Johnsen 2005; Choi et al. 2010). These processes are predetermined by physical and chemical properties of the lighter fraction PAHs such as low molecular weight, high vapor pressure and high volatility rate (Mackay and Hickie 2000). Volatilization was proved to play the most significant role in the global degradation of the 2- and 3-ringed PAHs especially. Park et al. (1990) reported that approximately $30 \%$ loss of naphthalene accounts for volatilization, while for the remaining compounds this process was insignificant. Heavy weight PAHs, i.e. 4-6-ring compounds, have low solubility in water and low volatility, strong affinity to particulates (BC and SOM, fine fractions), are less accessible for biological uptake and degradation and thus are more persistent in the environment (Johnsen et al. 2005; Haritash and Kaushik 2009). It has been proven that PAHs may form nonextractable $\left[{ }^{14} \mathrm{C}\right] \mathrm{PAH}$ residues in soil under the stimulation of microbial activity, which obviously leads to unexpectable lower results while analyzing the concentrations of naphthalene, anthracene, pyrene and benzo(a) pyrene in soil samples (Eschenbach et al. 1994, 1998).

The differences in levels of analyzed PAHs were tested using Post-hoc Fisher LSD test. The results showed significant differences in concentrations of the sum of 14 PAHs in $0-5 \mathrm{~cm}$ layer between meteorological station and both scientific research station and background site ( $p$ ANOVA $=<0.001)$, however comparison of scientific research station with background site revealed no significant differences. Statisticaly significant differences were also noted in concentrations of individual PAHs, particularly PHE, ANT, BbF and BaP $(p$ ANOVA $=0.02-0.04)$.

\section{Conclusions}

Complex soils geochemical investigation were carried on pristine soils of the Beliy Island situated in the Kara Sea, Yamal autonomous region, North-West Siberia, Russia. Beliy Island is considered as reference landscape for further investigation of soil polychemical contamination of the Yamal region. Three plots with different functional load (pristine ecosystem, occasionally and permanently affected plots) were investigated with aim to evaluate the trend 
of long term polychemical effect on Stagnic Cryosols - benchmark soil type of the Yamal region. There was no accumulation of trace elements fixed in all soils investigated. This could relate to absence of direct sources of heavy metals on the Beliy Island. At the same time there were essential alterations of PAHs fractional composition and content due to pronounced accumulation of the petroleum products combustion in the vicinity of the permanent meteorological station and former seasonal field base. The results of the study showed the influence of anthropogenic activity on the PAHs levels in soils of Beliy Island. The dominant individual PAHs are PHE, FLT and PYR - pyrogenically formed PAHs, originated from organic fuel, coal and wood combustion. Elevated total benzo[a]pyrene equivalents levels indicate a considerable anthropogenic load on soils near the permanent and seasonal stations. At the same time, no signs of accumulation of inorganic contaminants were noted.

Acknowledgements. - This work was supported by Russian Foundation for basic research, project No 16-34-60010, project No 16-45-890312 and logistically supported by the Government of Yamal-Nenets Autonomous region. We are also grateful to T. Walker and an anonymous reviewer for their valuable comments on the manuscript.

\section{References}

ABAKUMOV E. and TOMASHUNAS V. 2016. Electric resistivity of soils and upper permafrost layer of the Gydan Peninsula. Polarforschung 86(1): 27-34.

Abakumov E.V., Tomashunas V.M., Lodygin E.D., Gabov D.N., SoKolov V.T., KrylenKOV V.A. and KIRTSIDELI I.Y. 2015. Polycyclic aromatic hydrocarbons in insular and coastal soils of the Russian Arctic. Eurasian Soil Science 48(12): 1300-1305.

ACIA. 2005. Arctic climate impact assessment. Cambridge University Press, Cambridge: 1042 pp. AKeredolu F.A., BArRie L.A., Olson M.P., OiKaWA K.K., PACYNA J.M. and KeEler G.J. 1994. The flux of anthropogenic trace metals into the Arctic from the mid-latitudes in 1979/80. Atmospheric Environment 28: 1557-1572.

AleKseev I.I., AbAKumov E.V., SHAMilishVILI G.A. and Lodygin E.D. 2016. Heavy metals and hydrocarbons content in soils of settlements of the Yamal-Nenets autonomous Okrug. Gigiena i Sanitariya 95(9): 818-821 (in Russian).

ALEKSEEV I., KOSTECKI J. and ABAKUMOV E. 2017. Vertical electrical resistivity sounding (VERS) of tundra and forest tundra soils of Yamal region. International Agrophysics 31(1): 1-8.

Alyabina I.O., ANDrokhanov V.A., Vershinin V.V., VolKov S.N., GANZHARA N.F., Dobrovol'skiY G.V., IVANOV A.V., IVANOV A.L., IVANOVA YE.A., IL'IN L.I., KARPACHEVSKIY M.L., Kashtanov A.N., KiryUshin V.I., Kolesnikova V.M., Kolesnikova L.G., LOYKo P.F., MANYlov I.YE., MARECHEK M.S., MAKhinOva A.F., MOLCHANOV E.N., PROKHOROV A.N., PYAGAY E.T., ROZHKOV V.A., RYBAL'SKIY N.N., SAVIN I.YU., SAMOYLOVA N.S., Sapozhnikov P.M., Sizov V.V., Stolbovoy V.S., SuKhanov P.A., URUSEVSKaYa I.S., Chochayev A.KH., Sheremet B.V., Shoba S.A. and Yakovlev A.S. 2014. Unified State Register of Russian soil resources. Version 1.0. The collective monograph. Pochvennyy in-t im. V.V. Dokuchayeva Rossel'khozakademii, Moscow: 768 pp. (in Russian). 
Antsibor J., Zubriskiy S., Eshenbach A., KutZBACH L., BolshiYAnOv D. and Preifer E.-M. 2014. Trace metals distribution in pristine permafrost-affected soils of the Lena river delta and its hinterland, Northern Siberia, Russia. Biogeosciences 11: 1-15.

BARRIE L.A. 1985. Five years of chemistry observations in the Canadian Arctic. Atmosperic Environment 19: 1995-2010.

Barrie L.A., Gregor D., Hargrave B., Lake R., Muir D., Shearer R., Tracey B. and BildeMAN T. 1992. Arctic contaminants: sources, occurrence and pathways. Science of Total Environment 122: 1-74.

BEHYMER T.D. and HITES R.A. 1985. Photolysis of polycyclic aromatic hydrocarbons adsorbed on simulated atmospheric particulates. Environmental Science \& Technology 19(10): 1004-1006.

BEZNOSIKOV V.A. and LODYGIN E.D. 2014. Hydrocarbons in the background soils of the southernand middle-taiga subzones of the Komi Republic. Eurasian Soil Science 47(7): 682-686.

BEZNOSIKOV V.A., LODYGIN E.D. and KONDRATENOK B.M. 2007. Assessment of background concentrations of heavy metals in soils of the northeastern part of European Russia. Eurasian Soil Science 40: 949-955.

Budzinski H., Jones I., BellocQ J., PIERARD C. and GarRigues P.H. 1997. Evaluation of sediment contamination by polycyclic aromatic hydrocarbons in the Gironde estuary. Marine Chemistry 58: 85-97.

ChOI H.G., Moon H.B., CHOI M., YU J. and KIM S.S. 2010. Mussel watch program for organic contaminants along the Korean coast, 2001-2007. Environmental Monitoring and Assessment 169: 473-474.

DRUZHININ A.N., IDRISOV I.R. and MARSHININ A.V. 2015. The experience of mapping the Arctic tundra landscape on the example of northwestern part of Beliy Isalnd (Kara Sea). Geoinformatsionnoye kartografirovaniye $v$ regionakh Rossii: materialy VII Vserossiyskoy nauchno-prakticheskoy konferentsii Voronewzh: 46-54 (in Russian).

EJARQUE E. and ABAKUMOV E. 2016. Stability and biodegradability of organic matter from Arctic soils of Western Siberia: Insights from 13C-NMR spectroscopy and elemental analysis. Solid Earth 7(1): 153-165.

ESCHENBACH A., KÄSTNER M., BIERL R., SCHAEFER G. and MAHRo B. 1994. Evaluation of a new, effective method to extract polycyclic aromatic hydrocarbons from soil samples. Chemosphere 28(4): 683-692.

ESCHENBACH A., WiENBERG R. and MAHRO B. 1998. Fate and stability of nonextractable residues of [14C]PAH in contaminated soils under environmental stress conditions. Environmental Science \& Technology 32(17): 2585-2590.

FORSTNER U. 1990. Inorganic sediment chemistry and elemental speciation. In: R. Baudo, J.P. Giesy and H. Muntau (eds.) Sediments: Chemistry and Toxicity of In-Place Pollutants. Lewis Publishers, Boca Raton: 61-105.

GABOv D.N., BEZnOSIKOV V.A. and KondRATENKo B.M. 2007. Polycyclic aromatic hydrocarbons in background podzolic and gleyic peat-podzolic soils. Eurasian Soil Science 40(3): 256-264.

Gabov D.N., BEZnosikov V.A. and KONDRATENKo B.M. and YAKOVLEVA E.V. 2008. Formation of polycyclic aromatic hydrocarbons in northern and middle taiga soils. Eurasian Soil Science 41: $1180-1188$.

GorYaChKIN S.V. 2010. Soil Cover of the North (Patterns, Genesis, Ecology, Evolution). Publishing house GEOS, Moscow: $414 \mathrm{p}$.

GN 2.1.7.2041-06. 2006. Maximum permissible concentrations of chemical substances in soils. (in Russian). FSE Research Institute of Human Ecology and Environmental Health named after L.N. Sysin RAMS. http://docs.cntd.ru/document/901966754 
GN 2.1.7.2511-09. 2009. Approximate permissible concentrations of chemical substances in soils. (in Russian). FSE Research Institute of Human Ecology and Environmental Health named after L.N. Sysin RAMS. http://docs.cntd.ru/document/902163355

HARITASH A.K. and KAUSHIK C.P. 2009. Biodegradation aspects of polycyclic aromatic hydrocarbons (PAHs): a review. Journal of Hazard Materials 169(1): 1-15.

Hudson L.N., Newbold T., Contu S., Hill S.L., Lysenko I., De Palma A. and Choimes A. 2014. The PREDICTS database: a global database of how local terrestrial biodiversity responds to human impacts. Ecology and Evolution 4(24): 4701-4735.

Hudson L.N., Newbold T., Contu S., Hill S.L., Lysenko I., De Palma A. and Booth H. 2017. The database of the PREDICTS (Projecting Responses of Ecological Diversity In Changing Terrestrial Systems) project. Ecology and Evolution 7(1): 145-188.

HWANG H.M., WADE T.L. and SERICANO J.L. 2003. Concentrations and source characterization of polycyclic aromatic hydrocarbons in pine needles from Korea, Mexico, and United States. Atmospheric Environment 37(16): 2259-2267.

JOHNSEN A.R., WiCK L.Y. and HARMS H. 2005. Principles of microbial PAH-degradation in soil. Environmental pollution 133(1): 71-84.

KaVerin D.A., Pastukhov A.V. and Majtova G.G. 2014. Temperature regime of the tundra soils and underlaying permafrost (Northeast European Russia). Kriosfera Zemli 18(3): 23-31 (in Russian).

Kimble J.M. (ed.) 2004. Cryosols: Permafrost-affected Soils. Springer-Verlag, Berlin: 726 pp.

KHITUN O. and REBRISTAYA O. 1997. The specific of the compound of species colonizing disturbed habitats in Central Yamal. In: E.G. Kuznetsova (ed.) Development of the North and problems of recultivation. Proceedings of the III international conference 1996 May 27-31; St. Petersburg, Syktuvkar: 132-141. (in Russian).

Kotlyakov V. and Khromova T. 2002. In: V. Stolbovoi and I. McCallumm (eds) Land Resources of Russia Laxenburg, Austria, International Institute for Applied Systems Analysis and the Russian Academy of Science, CD-ROM, Distributed by the National Snow and Ice Data Center, Boulde.

Lodygin E., BeZnosiKov V., ABAKUmOV E.V. 2017. Humic substances elemental composition of selected taiga and tundra soils Russian European North. Polish Polar Research 38: 125-147.

MACASKILl N.D., WALKER T.R., OAKES K. and WALSH M. 2016. Forensic assessment of polycyclic aromatic hydrocarbons at the former Sydney Tar Ponds and surrounding environment using fingerprint techniques. Environmental Pollution 212: 166-177.

MACKAY D. and HiCKIE B. 2000. Mass balance model of source apportionment, transport 482 and fate of PAHs in Lac Saint Louis, Quebec. Chemosphere 41(5): 681-692.

Makarova O.L., Ermilov S.G., Yurtaev A.A. and Mansurov R.I. 2015. The first data on the soil mites (Acari) of the arctic Belyi Island (Northern Yamal, the Kara sea). Entomological Review 6: 805-810.

MASClet P., BReSSON M.A. and Mouvier G. 1987. Polycyclic aromatic hydrocarbons emitted by power stations, and influence of combustion conditions. Fuel 66(4): 556-562.

MAZHAROV A.V. 2012. Rehabilitation of the Beliy Island - one of the priorities of the management of the Yamal-Nenets Autonomous District. Arkticheskiye vedomosti 3: 134-139 (in Russian).

MoskovCHENKo D.V. 1998. Oil and gas development and environmental pollution: Ecologico-geochemical analysis of Tyumen oblast. Federal'noye gosudarstvennoye unitarnoye predpriyatiye "Akademicheskiy nauchno-izdatel'skiy, proizvodstvenno-poligraficheskiy i knigorasprostranitel'skiy tsentr", Nauka. Novosibirsk: 112 pp. (in Russian).

MoskovchenKo D.V. 2011. Biogeochemical structure of cryogenic landscapes of Western Siberia as an indicator of environmental status and stability. Kriosfera Zemli 4: 29-32 (in Russian). 
Moskovchenko D.V. 2013. Ecogeochemistry oil and gas regions of Western Siberia. Akademicheskoye izdatel'stvo «Geo». Novosibirsk: 259 p. (in Russian).

MULLER G. 1979. Schwermetalle in den sediment des Rheins, Veranderungem Seit 1971. Umschau, 79: 778-783.

Nikitina M., Popova L., Korobicina J., Efremova O., Trofimova A., NaKvasina E. and VOLKOV A. 2015. Environmental Status of the Arctic Soils. Journal of Elementology 20: 643-651.

PARK K.S., SiMS R.C. and DUPONT R.R. 1990. Transformation of PAHs in soil systems. Journal of Environmental Engineering 116: 632-640.

PND F 16.1:2.3:3.11-98. 1998. Quantitative Chemical Analysis of Soils: Procedure for Measuring the Content of Metals in Solid Bodies by Inductively Coupled Plasma Spectrometry (in Russian).

PND F 16.1: 2.21-98. 1998. Methods of measurement of mass fraction of oil in the samples of soil and ground by fluorimetric method using liquid analyzer «Fluorat-02.» M. (in Russian).

PND F 16.1:2.2:2.3:3.62-09. 2009. Quantitative chemical analysis of soils. A method for measuring of the mass fractions of polycyclic aromatic hydro carbons in soils, bottom sediments, sediments of waste waters, and industrial wastes by high performance liquid chromatography (in Russian).

ReBristaya O.V. 2013. Flora of Yamal Peninsula. LETI, Sankt-Peterburg: 311 pp. (in Russian).

REBRISTAYA O.V. and KHITUN O.V. 1997. Restoration potential of the Yamal flora. In: E.G. Kuznetsova (ed.) Development of the North and problems of recultivation. Proceedings of the III international conference 1996 May 27-31; St. Petersburg, Syktuvkar: 100-107 (in Russian).

Rovinsky F., Pastuchov B., Bouyvolov Y. and BuRTSEVA L. 1995. Present day state of background pollution of the natural environment in the Russian Arctic in the region of the Ust-Lena Reserve. Science of Total Environment. 160/161: 193-199.

Shishov L.L., TonKonogov V.D., LeBedeVA I.I. and GERASIMOVA M.I. 2004. Classification and diagnostics of Russian soils. Oykumena, Smolensk: 341 pp. (in Russian).

SanPiN 42-128-4433-87. 1987. Sanitary norms for available concentrations of chemical compounds in soils (in Russian). http://www.gosthelp.ru/home/download.php?view.4439

Slagoda A., Leibman M.O., Khomutova V. and OReKhov P.T. 2013. Cryolithologic construction of the first terrace at Bely Island, Kara Sea (part 1). Kriosfera Zemli 4: 11-21 (in Russian).

Thomas D.J., Tracey B., Marshall H. and Norstrom R.J. 1992. Arctic terrestrial ecosystem contamination. Science of Total Environment 122: 135-164.

TOMASHUNOS V.M. and ABAKUMOV E.V. 2014. The content of heavy metals in soils of the Yamal Peninsula and the Bely Island. Gigiena i sanitaria 93 (6): 26-31 (in Russian).

TROFIMOVA I.E. and BALYBINA A.S. 2014. Classification of climates and climatic regionalization of the West-Siberian plain. Geography and Natural Resources 35(2): 114-122.

US EPA. 1996a. Method 8310: Polynuclear Aromatic Hydrocarbons. In: Test Methods for Evaluating Solid Waste, Physical/Chemical Methods; Third Edition; Final Update 3-A. National Service Center for Environmental Publications (NSCEP) of the US Environmental Protection Agency, Washington DC: Office of Health and Environmental Assessment. Revision 0. http:// nepis.epa.gov/Exe/ZyPURL.cgi?Dockey=50000U6E.txt. Accessed 20 April 2015.

US EPA. 1996b. Method 3550b: Ultrasonic extraction. In: Test Methods for Evaluating Solid Waste, Physical/Chemical Methods; Third Edition; Final Update 3-A. National Service Center for Environmental Publications (NSCEP) of the US Environmental Protection Agency, Washington DC: Office of Health and Environmental Assessment. Revision 2. http://nepis.epa.gov/Exe/ ZyPURL.cgi?Dockey=50000U6E.txt. Accessed 20 April 2015.

US EPA. 1996c. Method 3630c: Silica Gel Cleanup. In: Test Methods for Evaluating Solid Waste, Physical/Chemical Methods; Third Edition; Final Update 3-A. National Service Center for Environmental Publications (NSCEP) of the US Environmental Protection Agency, Washington 
DC: Office of Health and Environmental Assessment. Revision 3. http://www3 .epa.gov/epawaste/hazard/testmethods/sw846/pdfs/3630c.pdf. Accessed 20 April 2015.

Vlasov D.Y., Abakumov E.V., Tomashunas V.M., KrylenKov V.A. and Zelenskaya M.S. 2014. Mycobiota of soil and anthropogenic substrates of the Yamal Peninsula. Gigiena i sanitariia 5: 49-51 (in Russian).

WALKER T.R. 2012. Properties of selected soils from the sub-Arctic region of Labrador, Canada. Polish Polar Research 33(3): 207-224.

WALKer T.R., Young S.D., CRITTENDEN P.D. and ZhANG H. 2003a. Anthropogenic metal enrichment of snow and soil in north-eastern European Russia. Environmental Pollution 121: 11-21.

WALKER T.R., CRITTENDEN P.D. and Yound S.D. 2003b. Regional variation in the chemical composition of winter snow pack and terricolous lichens in relation to sources of acid emissions in the Usa river basin, northeast European Russia. Environmental Pollution 125(3): 401-412.

WAlKer T.R., HABECK J.O., KARJAlainen T.P., VirTANEN T., SOlOVIEVA N., JONES V. and PATOVA E. 2006. Perceived and measured levels of environmental pollution: interdisciplinary research in the subarctic lowlands of northeast European Russia. AMBIO: A Journal of the Human Environment 35(5): 220-228.

Walker T.R., Crittenden P.D., Dauvalter V.A., Jones V., Kuhry P., Loskutova O. and PysTINA T. 2009. Multiple indicators of human impacts on the environment in the Pechora Basin, north-eastern European Russia. Ecological indicators 9(4): 765-779.

WANG R. and CADMAN P. 1998. Soot and PAH production from spray combustion of different hydrocarbons behind reflected shock waves. Combustion and Flame 112(3): 359-370.

WHO/IPCS. 1998. Environmental Health Criteria 202: Selected Non-Heterocyclic Polycyclic Aromatic Hydrocarbon. International Program on Chemical Safety, United Nations Environmental Program, World Health Organization. Geneva.

WILD S.R. and JONES K.C. 1995. Polynuclear aromatic hydrocarbons in the United Kingdom environment: a preliminary source inventory and budget. Environmental pollution 88(1): 91-108.

Yunker M.B., Macdonald R.W., Vingarzan R., Mitchell R.H., Goyette D. and SylvesTRE S. 2002. PAHs in the Fraser River basin: a critical appraisal of PAH ratios as indicators of PAH source and composition. Organic Geochemistry 33(4): 489-515.

Received 8 March 2017

Accepted 11 July 2017 